\title{
Analisis Kualitas Layanan Website Lazada Terhadap Kepuasan Pelanggan Menggunakan Metode WebQual
}

\author{
Nindy Apsari Ardiningrum \\ Program Studi Teknik Informatika, Fakultas Ilmu Komputer \\ Universitas Pembangunan Nasional "Veteran" Jawa Timur \\ Jl. Rungkut Madya, Gunung Anyar - Surabaya 60294 \\ E-mail : nindyapsra@gmail.com
}

\begin{abstract}
ABSTRAK
Abstract. This study attempts to analyze the quality of Lazada retail website services with the aim of knowing the level of satisfaction of website users. Lazada can provide services to the community in the form of convenience when searching for the desired product. However, there are still many users who feel the lack of accurate information from this website. Through the WebQual 4.0 approach, which is one of the techniques for measuring website quality, the assessment will focus on three main dimensions, namely the quality of usability, the quality of information, and the quality of service interactions. By using a descriptive approach, research data collection is done by distributing questionnaires to website users. After that, the data obtained will be analyzed using quantitative analysis. Data processing is done by SPSS to test its validity and reliability. Because it focuses on the perception of the quality of website services, it is expected that the results of this study can be used as feedback in improving the quality of Lazada's website in the future.
\end{abstract}

Keywords: Website Service Quality, Webqual, Descriptive Approach, Quantitative Analysis

\begin{abstract}
Abstrak. Penelitian ini mencoba melakukan analisis terhadap kualitas layanan website retail Lazada dengan tujuan untuk mengetahui tingkat kepuasan pengguna website. Lazada dapat memberikan layanan kepada masyarakat dalam bentuk kemudahan ketika melakukan pencarian produk yang diinginkan. Namun, masih banyak juga pengguna yang merasakan kurangnya informasi yang akurat dari website ini. Melalui pendekatan WebQual 4.0 yang merupakan salah satu teknik pengukuran kualitas website, penilaian akan difokuskan pada tiga dimensi utama yaitu kualitas kegunaan, kualitas informasi, dan kualitas interaksi layanan. Dengan menggunakan pendekatan deskriptif, pengumpulan data penelitian dilakukan dengan cara penyebaran kuesioner kepada pengguna website. Setelah itu, data yang didapat akan dianalisa menggunakan analisa kuantitatif. Pengolahan data dilakukan dengan SPSS untuk dilakukan uji validitas dan reliabilitasnya. Karena menitikberatkan pada persepsi mutu layanan website, maka diharapkan hasil penelitian ini mampu untuk dijadikan umpan balik dalam peningkatan kualitas website Lazada di masa mendatang.
\end{abstract}

Kata kunci: Kualitas Web Servis, Webqual, Pendekatan Deskriptif, Analisa Kuantitif

\section{Pendahuluan}

Lazada adalah salah satu situs belanja online yang menawarkan berbagai jenis produk. Mulai dari elektronik, buku, mainan anak, dan perlengkapan bayi, alat kesehatan dan produk kecantikan, peralatan rumah tangga, fashion, serta perlengkapan traveling dan olahraga. Situs ini adalah situs yang memanfaatkan kemajuan teknologi, karena penggunaannya yang mengharuskan dengan akses internet. Karena bentuk informasinya melalui website atau World Wide Web (WWW), semakin memudahkan pengguna dalam melakukan pengkasesan.

Situs ini hadir secara responsif untuk memenuhi kebutuhan masyarakat akan informasi mengenai produk-produk yang sekiranya dibutuhkan masyarakat. Berhasil menempati posisi ke 19 di Indonesia menurut Alexa, situs yang beralamatkan www.lazada.co.id ini bisa dikatakan memiliki kualitas yang cukup baik dibandingkan beberapa website toko online lainnya. Namun, kualitas website tidak bisa hanya dinilai begitu saja. Dengan penilaian kualitas website menggunakan metode WebQual, ada 
dimensi penilaian khusus yang harus dinilai seperti usability, information quality, dan service interaction.
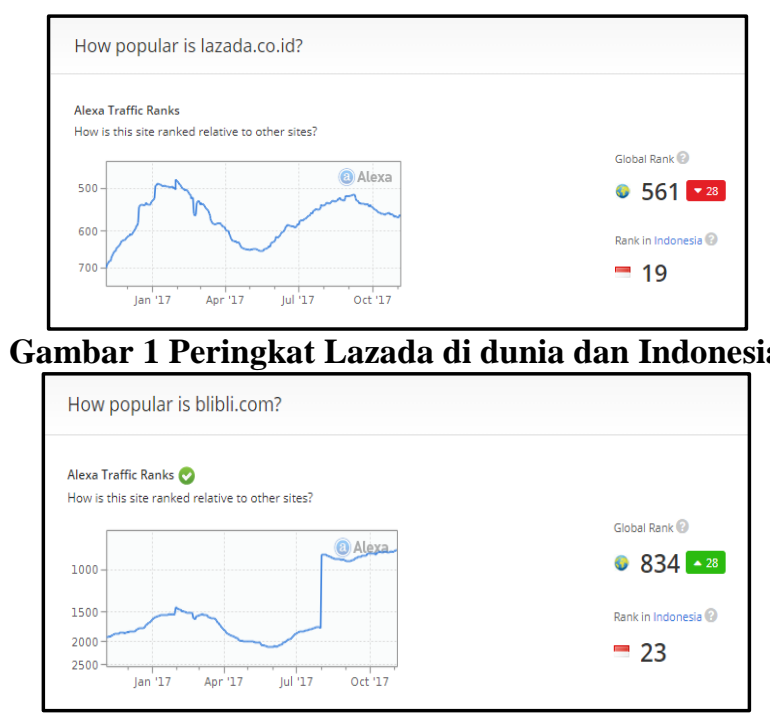

Gambar 2 Peringkat Blibli di dunia dan Indonesia

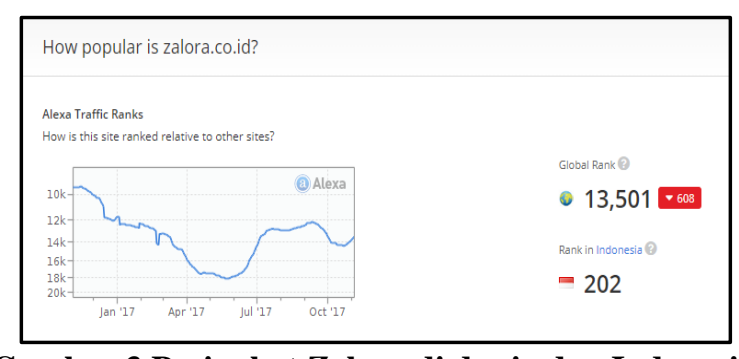

Gambar 3 Peringkat Zalora di dunia dan Indonesia

Berdasarkan uraian diatas, identifikasi masalah yang ada pada website www.lazada.co.id adalah sebagai berikut :

1. Bagaimana menentukan aspek yang mempengaruhi peningkatan kualitas dari website Lazada?

2. Bagaimana pengaruh dimensi variabel WebQual pada kualitas website Lazada?

3. Bagaimana menilai kepuasan pelanggan terhadap website Lazada?

a. Sedangkan tujuan penelitian ini adalah :

4. Untuk mengetahui apakah website Lazada sudah berjalan sesuai dengan kebutuhan dan keperluan pengguna atau belum

5. Untuk mengetahui pengaruh website quality terhadap kepuasan pelanggan

\section{Tinjauan Pustaka}

\subsection{Kualitas}

Menurut Dorothea (2004), konsep kualitas harus bersifat menyeluruh, baik produk maupun prosesnya. Kualitas produk meliputi kualitas bahan baku dan barang jadi, sedangkan kualitas proses meliputi segala sesuatu yang berhubungan dengan proses produksi perusahaan manufaktur dan proses penyediaan jasa atau pelayanan perusahaan jasa. Kualitas harus dibangun sejak awal, dari penerimaan input hingga perusahaan menghasilkan ouput bagi pelanggannya [1]. 


\subsection{Website}

Menurut Gregorius (2000), website merupakan sejalan halaman web yang saling terhubung dan file-filenya saling terkait [2]. Hampir mirip dengan Gregorius, Rahmat (2010) mengungkapkan bahwa website adalah keseluruhan halaman-halaman web yang terdapat dalam sebuah domain yang mengandung informasi [3].

\subsection{WebQual}

WebQual merupakan salah satu metode atau teknik pengukuran kualitas situs berdasarkan persepsi pengguna akhir

\subsection{Kuesioner}

Kuesioner merupakan teknik pengumpulan data dengan cara tertulis pertanyaan kepada responden untuk dijawab. Kuesioner merupakan teknik pengumpulan data yang efisien bila peneliti tahu dengan pasti variabel yang akan diukur dan tahu apa yang bisa diharapkan dari responden [4].

\subsection{Uji Validitas}

Sebuah item yang mempunyai korelasi yang positif dengan skor total serta korelasi yang tinggi, menunjukkan item tersebut mempunyai validitas yang tinggi juga. Pengujian statistik mengacu pada :

1. $\mathrm{r}$ hitung $<\mathrm{r}$ tabel maka tidak valid

2. $r$ hitung $>r$ tabel maka valid

\subsection{Uji Reliabilitas}

Setelah dilakukan uji validitas atas pertanyaan yang diajukan melalui kuesioner, selanjutnya akan dilakukan uji realibilitas yang bertujuan untuk mengetahui ketepatan, keakuratan, kestabilan atau konsistensi. Dalam pengujian ini terdapat istilah nilai kritis yang telah ditetapkan yaitu 0,6. Adapun acuan dari uji reliabilitas adalah :

(1) jika nilai alpha $>0,6$ maka reliabel

(2) jika nilai alpha $<0,6$ maka tidak reliabel

\section{Metode Penelitian}

\subsection{Jenis Penelitian}

Sesuai dengan tujuan penelitian ini, yaitu untuk mengetahui kepuasan pelanggan menggunakan metode WebQual, maka jenis penelitian yang digunakan adalah penelitian deskriptif kuantitatif.

Penelitian deskriptif adalah penelitian yang menggunakan pendekatan dengan menggunakan gambaran karakteristik objek, manusia, kelompok, organisasi atau lingkungan. Bisa dikatakan bahwa penelitian dengan pendekatan deskriptif harus bisa menggambarkan situasi yang terkait dengan pertanyaan siapa, apa, kapan, dimana dan bagaimana.

Sedangkan kuantitatif yang digunakan pada penelitian ini adalah metode analisis. Metode ini menjelaskan bahwa proses penganalisisan menekankan pada pengujian teori melalui pengukuran variabel dengan angka melalui prosedur statistik.

\subsection{Metode}

Dengan menerapkan metode pendekatan deskriptif, maka proses pengumpulan data dilakukan dengan cara pengambilan sampel kuesioner secara acak kepada 30 pengguna website Lazada. Adapun daftar pertanyaan yang diberikan kepada responden adalah meliputi 3 dimensi website quality, antara lain seperti pada pada tabel berikut.

Tabel 1 dimensi website quality

Dimensi Kualitas Web $\quad$ WebQual Item




\begin{tabular}{|c|c|}
\hline Usability & $\begin{array}{ll}\text { 1. } & \text { Situs mudah dipelajari dan dioperasikan } \\
\text { 2. } & \text { Interaksi dengan situs jelas dan dimengerti } \\
\text { 3. } & \text { Situs ini memiliki petunjuk yang jelas } \\
\text { 4. } & \text { Situs mudah digunakan } \\
\text { 5. } & \text { Situs memiliki tampilan yang menarik } \\
\text { 6. } & \text { Desainnya sesuai dengan tipe situsnya } \\
\text { 7. } & \text { Situs ini meningkatkan kompetensi/persaingan } \\
\text { 8. } & \text { Situs ini membawa dampak yang positif untuk saya }\end{array}$ \\
\hline Information Quality & $\begin{array}{l}\text { 1. Memberikan informasi yang akurat } \\
\text { 2. Memberi informasi yang terpercaya } \\
\text { 3. Memberi informasi yang tepat waktu/update } \\
\text { 4. Memberi informasi yang relevan } \\
\text { 5. Memberi informasi yang mudah dimengerti } \\
\text { 6. Memberi informasi secara detail } \\
\text { 7. Memberikan informasi dengan bentuk penyajian } \\
\text { yang baik }\end{array}$ \\
\hline Service Interaction Quality & $\begin{array}{l}\text { 1. Situs menunjukkan reputasi yang baik } \\
\text { 2. Situs ini aman untuk melakukan transaksi } \\
\text { 3. Informasi pribadi tersimpan dengan aman } \\
\text { 4. Situs tersebut menciptakan kesan personal } \\
\text { 5. Situs tersebut memiliki komunitas } \\
\text { 6. Mempermudah untuk berkomunikasi dengan } \\
\text { organisasi situs tersebut } \\
\text { 7. Yakin bahwa pelayanan akan baik sesuai dengan } \\
\text { yang dijanjikan }\end{array}$ \\
\hline
\end{tabular}

\subsection{Uji Validitas}

\section{. Hasil Dan Pembahasan}

Uji validitas menggunakan batasan $r$ tabel dengan signifikan 0,05 dan uji 2 sisi. Untuk batasa $r$ tabel dengan $n=30$ maka didapatkan $r$ tabel sebesar 0,361 yang berarti jika nilai korelasi lebih dari 0,361 maka item tersebut dianggap valid. Sedangkan jika kurang dari 0,361, maka item dianggap tidak valid.

Tabel 2. Uji Validitas

\begin{tabular}{|c|c|c|}
\hline Nama Item & $\mathbf{r}_{\mathbf{x y}}$ & Ket \\
\hline Item 1 & 0,670 & Valid \\
\hline Item 2 & 0,410 & Valid \\
\hline Item 3 & 0,711 & Valid \\
\hline Item 4 & 0,755 & Valid \\
\hline Item 5 & 0,741 & Valid \\
\hline Item 6 & 0,831 & Valid \\
\hline Item 7 & 0,487 & Valid \\
\hline Item 8 & 0,846 & Valid \\
\hline Nama Item & $\mathbf{r}_{\mathrm{xy}}$ & Ket \\
\hline Item 1 & 0,800 & Valid \\
\hline Item 2 & 0,725 & Valid \\
\hline
\end{tabular}




\begin{tabular}{lll}
\hline Item 3 & 0,693 & Valid \\
\hline Item 4 & 0,396 & Valid \\
\hline Item 5 & 0,831 & Valid \\
\hline Item 6 & 0,250 & Tidak Valid \\
\hline Item 7 & 0,846 & Valid \\
\hline Item 8 & 0,598 & Valid \\
\hline Nama Item & \multicolumn{1}{c}{ ry } & Ket \\
\hline Item 1 & $\mathbf{0 , 3 0 8}$ & Tidak Valid \\
\hline Item 2 & $\mathbf{- 0 , 0 3 6}$ & Tidak Valid \\
\hline Item 3 & $\mathbf{0 , 1 4 5}$ & Tidak Valid \\
\hline Item 4 & $\mathbf{0 , 1 4 7}$ & Tidak Valid \\
\hline Item 5 & $\mathbf{0 , 6 9 6}$ & Valid \\
\hline Item 6 & $\mathbf{0 , 4 6 9}$ & Valid \\
\hline Item 7 & $\mathbf{0 , 0 9 3}$ & Tidak Valid \\
\hline
\end{tabular}

Dari tabel diatas dapat dilihat bahwa pada dimensi usability memiliki indikator yang seluruhnya valid. Sedangkan pada dimensi information quality memiliki 7 indikator valid dan 1 indikator yang tidak valid. Dan untuk dimensi service interaction quality hampir sebagian besar indikatornya tidak valid dimana hanya terdapat dua indikator yang valid dan 5 lainnya tidak valid. Oleh karena itu, indikator yang memiliki nilai tidak valid, akan dihapus supaya bisa dilanjutkan ke tahapan analisis selanjutnya.

Tabel 3. Uji Validitas 2

\begin{tabular}{|c|c|c|}
\hline Nama Item & $\mathbf{r}_{\mathrm{xy}}$ & Ket \\
\hline Item 1 & 0,670 & Valid \\
\hline Item 2 & 0,410 & Valid \\
\hline Item 3 & 0,711 & Valid \\
\hline Item 4 & 0,755 & Valid \\
\hline Item 5 & 0,741 & Valid \\
\hline Item 6 & 0,831 & Valid \\
\hline Item 7 & 0,487 & Valid \\
\hline Item 8 & 0,846 & Valid \\
\hline Nama Item & $\mathbf{r}_{\mathrm{xy}}$ & Ket \\
\hline
\end{tabular}




\begin{tabular}{lll} 
Item 1 & 0,800 & Valid \\
\hline Item 2 & 0,725 & Valid \\
\hline Item 3 & 0,693 & Valid \\
\hline Item 4 & 0,396 & Valid \\
\hline Item 5 & 0,831 & Valid \\
\hline Item 7 & 0,846 & Valid \\
\hline Item 8 & 0,598 & Valid \\
\hline Nama Item & \multicolumn{1}{c}{$\mathbf{r}_{\mathbf{x y}}$} & Ket \\
\hline Item 5 & 0,696 & Valid \\
\hline Item 6 & 0,469 & Valid
\end{tabular}

\subsection{Uji Reliabilitas}

Uji reliabilitas digunakan untuk menguji konsistensi alat ukur, apakah hasil yang didapat sudah mendapatkan nilai yang tetap atau perlu dilakukan pengulangan.

Tabel 4. Uji Realibilitas

Cronbach's Alpha $\mathbf{N}$ of Items

$\overline{762} 16$

Koefisien alpha digunakan sebagai ukuran konsistensi internal. Seperti pada teori yang telah dijelaskan sebelumnya, alpha yang dihasilkan adalah 0,762 yang berarti alpha tersebut $>0,6$, sehingga dapat dinyatakan bahwa data tersebut layak digunakan.

Dengan demikian, setelah melewati satu putaran, maka ke-16 butir didalam kuesioner tersebut adalah valid dan reliabel. Penelitian ini bertujuan untuk memeriksa hubungan antara variabel dependen dan variabel independen. Model analisis regresi dapat digunakan untuk menyelesaikan permasalahan yang melibatkan lebih dari dua variabel.

\section{Kesimpulan Dan Saran}

\subsection{Kesimpulan}

Berdasarkan hasil pengolahan data dan analisa yang telah dilakukan mengenai pengukuran kualitas website dengan menggunakan metode webqual, dapat disimpulkan mengenai hal-hal sebagai berikut :

1. Faktor yang mempengaruhi kepuasan pengguna terhadap kualitas website Lazada adalah dimensi usability, information quality, dan service interaction quality

2. Kualitas informasi yang disediakan oleh website dianggap masih kurang memberikan kepuasan pada pelanggan

3. Kualitas interaksi antara website dengan pelanggan juga masih sangat jauh dari harapan dan keinginan pelanggan.

\subsection{Saran}


1. Hendaknya pengelola situs website lebih mempertimbangkan kualitas isi dari website seperti kejujuran dari setiap produk yang dijual ataupun kelengkapan informasi mengenai suatu produk.

2. Analisa kepuasan ini alangkah baiknya jika dilanjutkan dengan cara membandingkan hasil kepuasan pelanggan tahun ini dengan tahun-tahun berikutnya.

\section{Daftar Pustaka}

Ariani, Dorothea Wahyu, Pengendalian Kualitas Statistik (Pendekatan Kuantitatif dalam Manajemen Kualitas). Yogyakarta: Andi Ofset. 2004

Agung, Gregorius. "Tips \& Trik Membuat Efek Spesial Website dengan Dreamweaver 4". Elex Media Komputindo, Jakarta: 2000

Hidayat, Rahmat. Cara Praktis Membangun Website Gratis. Jakarta: Elex Media Komputindo. 2004

Manik, Agnes, Salamah, Irma, dkk. Metode WebQual 4.0 untuk Evaluasi Kualitas Website Politeknik Negeri Sriwijaya. Palembang: Prosiding SNATIF Ke-4. 2007 